DOI: $10.2478 /$ rpp-2018-0002

Doctor of Science in Pedagogy, Full Professor, LYUDMYLA SUSHCHENKO

M. P. Drahomanov National Pedagogical University

Address: 9 Pyrohov St., Kyiv, 01601, Ukraine

E-mail: ludapeti@ukr.net

$\mathrm{PhD}$ in Physical Education and Sport, Associate Professor, OLEG BAZYLCHUK

Khmelnytskyi National University

Address: 11 Instytutska St., Khmelnytskyi, 29016, Ukraine

E-mail: oleg.bazylchuk@gmail.com

\title{
COMPARATIVE ANALYSIS OF PROFESSIONAL TRAINING OF FUTURE SPECIALISTS IN PHYSICAL THERAPY IN HIGHER EDUCATIONAL ESTABLISHMENTS OF UKRAINE AND EUROPE
}

\begin{abstract}
The article presents comparative analysis of the structure and content of future specialists in physical therapy training in higher educational establishments of Ukraine and leading European countries. Having analyzed official websites and educational documentation of the leading European colleges of higher education regarding professional training of future specialists in physical therapy, we have defined common and distinctive features of structural and content components of the process. Within the framework of the research, it has been found that in educational systems of Italy, Spain, Norway, Greece, Finland, Sweden, and Norway training of future specialists in physical therapy is primarily focused on the concept of continuous education and is variant, practice-oriented, related to the profession of a physical therapeutist at most. The research has revealed certain components in the structure and content of professional training of future specialists in physical therapy in higher educational establishments of Ukraine and leading European countries. These components can be used in structure-oriented content of educational process in Ukrainian higher educational establishments. Namely, these include: shift of the vector of educational process to practice-oriented education via increasing academic hours for improvement of professional competence of future specialists in physical therapy under conditions of actual professional activity, acquiring knowledge and skills necessary for professional activity. Relying on the results of the comparative analysis we have made a conclusion that positive experience in training of future specialists in physical therapy in higher educational establishments of Ukraine and leading European countries will allow to define the trend of developing professional training in domestic higher educational establishments.

Keywords: professional training, specialists, physical therapeutist, future specialists in physical therapy, higher education, higher educational establishments, structure of higher education, foreign experience.

\section{INTRODUCTION}

Socially significant changes in the system of higher education of Ukraine, aspiration for becoming a part of international educational field, the need in absolutely new generation of personnel having a degree of higher education and meeting the requirements of domestic and foreign labour markets call for essential modification of organization and content of higher education in our country.
\end{abstract}


Due to the factors stated above, improvement of the existing legal and educational regulations regarding training of future specialists in physical therapy in higher educational establishments of Ukraine, preserving former achievements and peculiarities of native traditions and taking into account experience gained in leading colleges of higher education of the world, is rather topical nowadays.

We think that professional training of future specialists in physical therapy should be analyzed from the point of view of modern days and tendencies of reformation in the sphere of higher education of Ukraine while taking into account foreign experience of professional training of future specialists in physical therapy in higher educational establishments of the world.

The analysis of foreign experience in training of future specialists in physical therapy as well as the analysis of structural and content aspects of the system of education with the purpose to adapt their most significant achievements to national system of higher education define topicality of the research.

\section{THE AIM OF THE STUDY}

The aim of the research is to present the results of comparative analysis of the structure and content of professional training of future specialists in physical therapy in higher educational establishments of Ukraine and leading European countries.

\section{THEORETICAL FRAMEWORK AND RESEARCH METHODS}

Basic aspects of professional training of future specialists in the field of health protection in developed countries of the world have been partially defined by native scientists. Thus, in his dissertation A. Hertsyk (2006) analyzes organizational and methodological aspects of training bachelors of physical rehabilitation in Canada. In his monograph R. Karpyuk (2010) reveals peculiarities of professional training of specialists in adaptive physical education in leading European countries and the USA. The dissertation of N. Byelikova (2012) reveals basic tendencies of training future specialists in physical rehabilitation in Russian Federation, describes experience of North America, Australia, Great Britain, and some European countries. S. Hug (2015) made a complete study of peculiarities of professional training of future specialists in physical rehabilitation in universities of Great Britain. In his monograph Yu. Lyannyi (2016) describes some aspects of professional training of future specialists in physical rehabilitation, their master's degree education in Baltic countries, Austria, the Netherlands, the USA, and Canada. The analysis of scientific references shows that native literature has limited number of works related to studies of foreign experience in professional training of future specialists in physical therapy.

To achieve the aim of the research, the following methods were used in this work: analysis, synthesis, contrasting and generalization of the obtained data.

\section{RESULTS}

Until 2016, professional training of future specialists in physical therapy (physical rehabilitation at that time) in Ukraine was still done in the sphere of physical education and sport. Now, professional training of future specialists in physical therapy has been moved from branch of studies 0102 "Physical Education, Sport and Human Health" to 22 "Health Protection."

According to the "Law of Ukraine On Higher Education", professional training of physical therapeutists in higher educational establishments of Ukraine consists of three levels: the first (bachelor's degree) is the period of studies lasting 3 years and 10 months totaling 180-240 ECTS credits; the second (master's degree) is obtained by education and 
vocational program of training or by education and scientific program of training. Education and vocational training program totals $90-120$ ECTS credits, education and scientific program is 120 ECTS credits. The third level (education and scientific) is a standard period of training for $\mathrm{PhD}$ in postgraduate courses and lasts for 4 years. The educational component of the training program for $\mathrm{PhD}$ totals $30-60$ ECTS credits.

The analysis of official websites and educational documentation of some domestic and leading European universities reveals common and divergent features and approaches in the structure and content of professional training of future specialists in physical therapy.

Thus, the structure of higher education in Italy is similar to the Ukrainian one and also consists of three levels:

- the first level "Corsi di Diploma Universitario" is an analogue for bachelor's degree. Up until recent times, the program of training for bachelor was designed for four years and then it was reduced to three years. The first three years of studies in Italian colleges of higher education envisage significant number of theoretical courses, internship, and semester examinations;

- the second level "Corsi di Laurea" lasts from two to three years and is an equivalent to master's degree. Normally, master's degree can be obtained after completing studies for bachelor's degree. Graduate studies are aimed at improvement of previously obtained skills;

- the third level of higher education in Italy "Corsi di Dottorato di Ricerca i Corsi di Perfezionamento" corresponds to European $\mathrm{PhD}$ and is aimed at research program of the highest level. After its completion, the graduates are awarded the degree of Doctor of Science (Dottore), which is considered to be academic and is needed only for those who plan to teach at a higher educational establishment (Education in Italy, 2018).

The education process of training of bachelors in physical therapy in one of the biggest universities of Italy lasts for three years (six semesters) totaling 180 ECTS credits.

An obvious difference of the system of education in Italy is absence of fixed education programs. Students of higher educational establishments of Italy form schedules of classes and examinations for themselves. Naturally, there are lectures and seminars; however, students can select teachers and courses. Such freedom of choice is aimed at promoting interest to studying the selected subjects (Education in Italy, 2018).

Structure and content of professional training of future specialists in physical therapy in higher educational establishments of Greece are slightly similar to the ones used in Ukraine. Higher education in Greece has three levels: the first is a basic level (undergraduate studies); the second one is specialty degree (graduate studies); the third one is higher research level (postgraduate studies) (Education in Greece, 2018).

Professional training of future specialists in physical therapy in higher educational establishments of Greece for bachelor's degree is done primarily at faculties of physical education and sport throughout four years. Education program totals 240 ECTS credits (60 credits per each year of studies).

Education by the program of the given major is focused on studying basic and specialized vocational subjects. System of evaluation is different in higher educational establishments of Greece. A 10-grade scale of evaluation is used in Greece, 5 being the passing grade. The level of knowledge below 4.9 is "unsatisfactory", from 5 to 6.9 - is "satisfactory", from 7 to 8.4 - is "good", from 8.5 to 10 - is "excellent". To score high grades is not an easy thing to do in Greek colleges of higher education. "Excellent" can only be scored for creative work and brilliant knowledge (Education in Greece, 2018). 
The system of higher education in Spain also consists of three levels: "Grado" lasts for four years and is an analogue to bachelor's degree; "Master" is one year of studies, and it is an analogue to master's degree; "Doctor" lasts for one year and is an analogue to postgraduate studies, which is completed by presenting a dissertation (Education in Spain, 2018).

Program of training for bachelors in physical therapy in most universities of Spain is designed for four years totaling 240 ECTS credits, which is similar to the one used in Ukrainian higher educational establishments. Educational workload is evenly spread throughout all four year of studies - 60 ECTS credits in each year.

Professional training of future specialists in physical therapy in Spanish higher educational establishments for bachelor's degree is done at faculties of medical sciences. Some universities offer training of such specialists by two programs: 1) Grau de Fisioteràpia (profound study of physiotherapy of locomotor apparatus, physiotherapy in neurology, and physiotherapy of cardiovascular system); 2) Grau de Fisioteràpia (escoles adscrites) physiotherapy in pediatrics, physiotherapy of thorax diseases, physiotherapy in sports.

Curriculum of professional training of future specialists in physical therapy in Spanish higher educational establishments is distinguished by twice lesser number of subjects (8-9 per academic year) in comparison to Ukrainian universities. The structure of curricula for the third and the fourth year of studies envisages field studies totaling 42 credits, which is three time more (13-15 credits) than in the majority of higher educational establishments of Ukraine.

Some divergent features have also been revealed in the content. Thus, distribution of the workload for the block of basic subjects in the first year of studies by both fields of training is $75 \%-48$ ECTS credits out of overall 60 credits in comparison to the number of compulsory subjects and 12 ECTS credits, which is $25 \%$. However, in the second year of studies, the volume of workload for the block of basic training subjects in both fields is only $25 \%$ (12 ECTS credits), while for block of compulsory subjects it is $75 \%$ (48 ECTS credits). In the third and fourth years of studies, the content of curriculum is formed by two blocks of subjects - compulsory and selective. In the third year of studies, the volume of workload for compulsory subjects is 48 ECTS credits (75\% of overall amount). The volume workload for the block of selective subjects is 12 ECTS credits ( $25 \%$ of overall number). In the fourth year of studies, specific load of the block of selective subjects is reduced to $60 \%$, while the number of compulsory subjects decreases to $20 \%$ of overall workload (Education in Spain, 2018).

The system of higher education in Finland is represented by two types of educational establishments: traditional universities (yliopisto, universitet) and polytechnic universities (ammattikorkeakoulu, yrkeshögskola). Professional training of specialists in Finnish higher educational establishments is done by the classic three-level system of higher education: undergraduate studies, graduate studies, and postgraduate studies. However, some features that are peculiar only to Finnish system of higher education should be noted (Education in Finland, 2018).

A significant number of professions (especially state-regulated) in Finland require a person to have master's degree, which is why undergraduate program of training in Finland is often viewed not as a complete higher education, but as preparation for the next level.

The duration of training for the bachelor's degree in traditional and polytechnic universities is different. Bachelor of Arts training lasts for 3 years with 180 ECTS credits. Polytechnic universities have Bachelor's degree programs for 3.5-4 years of studying with 210-240 ECTS credits. 
Unlike countries of Southern and Central Europe, that actively implement the system of free sciences and interdisciplinary programs, Finnish universities focus on one field.

A 5-grade scale of assessment is used in Finland (grade "0" exists but is used rather rarely). After finishing school a person may have high level of knowledge, however, in universities it is not like that. Average grade rarely reaches 4.0, but the reason is not poor educational performance, but harsher and stricter system of evaluation.

Students obtain bachelor's degree in physical therapy in most Finnish universities at the faculty of health protection and social welfare (Sosiaalija terveysala). Educational program for bachelor's degree in physical therapy, as in Helsinki Metropolia University of Applied Sciences, is designed for 3.5 years totaling 210 ECTS credits - 60 ECTS credits per first three years of studies and 30 ECTS credits in the last semester.

The content of curriculum comprises ten blocks of subjects that help form professional competencies of future physiotherapists: the first block is "personal skills" (Työelämävalmiudet); the second one is "General researches in the field of social issues and health protection" (Sosiaalija terveysalan yhteiset perusopinnot); the third block is "Interaction with clients under conditions of changing business environment" (Asiakkuus muuttuvassa toimintaympäristössä); the fourth one is "Basics of social welfare and health improvement" (Hyvinvoinnin ja terveyden edistämisen perusteet); the fifth one is "Methods of functional evaluation in physiotherapy" (Toimintakyvyn arviointi ja fysioterapian menetelmiä); the sixth one is "Improvement of health, physical activity and functional capabilities with the help of physiotherapeutic means" (Toimintakyvyn ja terveyden edistäminen fyysisen aktiivisuuden ja fysioterapian keinoin); the seventh one is "Challenges of international environment and technology in future"; the eighth block is "Practical studies" (Ammattitaitoa edistävä harjoittelu); the ninth block is "Entrepreneurship and innovations" (selective courses) (Yrittäjyys ja innovaatiotoiminta); and the tenth one is "diploma thesis" (Opinnäytetyö) (Education in Finland, 2018).

The system of higher education in Sweden is two-level (Education in Sweden, 2018). Higher education of the basic level is provided in the form of educational courses. At the same time, students can select individual courses and combine them. Credit units or points are awarded for each course. A student must get 60 points throughout one year. The diploma (hogskoleexamen) is given provided a student has at least 120 credit units (two years of full-time studies). Such diploma can be obtained in all universities or institutions. Bachelor's degree (kandidatexamen) envisages 180 credit units that can be scored throughout three years of study. To obtain master's degree (magisterexamen) a student has to score 120 credit units.

The second level - licentiate degree - (licentiatexamen) requires 120 credit units ( 2 years of studies and research work including diploma thesis) with at least 180 credit units from the first level of higher education. This degree can be awarded as intermediate for those who study by the program of doctorate degree (doktorsexamen). To obtain doctorate degree, at least four years of studies and 240 credit units are required.

Within the framework of bachelor's degree, educational program is focused on project- and problem-oriented analysis with implementation of case studies and application of new information technologies. Scientific approach and broad clinical education are also emphasized in the program. Throughout the entire undergraduate program, it is constantly evaluated, developed and updated taking into account the needs of society in physiotherapeutic help. 
In Sweden, physical therapeutists along with doctors and nurses are primary specialists in the sphere of health protection. Labor market gives broad range of opportunities for physical therapeutists. They can work in institutions of medical and sanitary help of closed or open type, in municipalities, business, private sector etc. Moreover, students have a chance to implement a certain part of their researches abroad via various exchange programs and agreements within universities.

In general, training of future specialists in physical therapy is designed for six semesters totaling 180 ECTS credits, 30 ECTS credits per semester. Two scales of evaluation are used in Swedish universities and colleges. The first - grades ranging from 1 (low level) to 5 (high level) - are usually used in technical universities. The second ne is used to evaluate performance of students from other specialties and includes only three types of grades: U (Underkänd) - "failed"; G (Godkänd) - "passed"; VG (Väl godkänd) "excellency" (Education in Sweden, 2018).

Comparative analysis of structure and content of bachelors in physical therapy training in leading universities of Norway (Education in Norway, 2018) and Khmelnytskyi National University (Khmelnytskyi National University, 2017) helped reveal common and divergent features and approaches. The common ones include: implemented degree systems of educations; application of credit system of education. Certain differences in the structure of educational programs used in universities of both countries have been revealed. Thus, educational program of training of physical therapy bachelors in universities of Norway is designed for three academic years. Educational program of Khmelnytskyi National University as well as of the majority of Ukrainian higher educational establishments is designed for four years of studies. Certain differences in the content of syllabuses used in universities of both countries have been revealed. The content of syllabuses used in Norwegian universities includes three-four major courses totaling from 10 to 40 ECTS credits per academic year. On the contrary, syllabus used in the Ukrainian university includes more courses $(8$ courses per each of four academic years) totaling 4-5 ECTS credits. Moreover, differences in educational workload have been revealed. In universities of Norway it comprises 180 ECTS credits, while in the Ukrainian higher educational establishments it comprises 240 ECTS credits. A significant advantage of Norwegian universities in terms of practical clinical experience (45 ECTS credits compared to 13 ECTS credits in Khmelnyskyi National University) has been revealed. The syllabus used in Norwegian universities envisages 15 ECTS credits for bachelor-degree thesis. We consider it to be a significant reserve for improvement of the process of future specialists in physical therapy training in our university (Education in Norway, 2018; Khmelnytskyi National University, 2017).

\section{CONCLUSIONS}

The analysis of official websites and educational documentation of leading colleges of higher education in leading European countries and Ukraine regarding professional training of future specialists in physical therapy allowed to define common and divergent features of structural component of educational process. The analysis of foreign experience of training future specialists in physical therapy will allow to implement positive experience of higher educational establishments of leading European countries in domestic higher educational establishments.

In future, the obtained results will serve as basis for the development of the concept and model of professional training of future specialists in physical therapy to work with athletes' health recreation. 


\section{REFERENCES}

1. Bielikova, N. (2012) Pidhotovka maibutnikh fakhivtsiv z fizychnoi reabilitatsii do zdoroviazberezhuvalnoi diialnosti: teoriia ta metodyka: monohrafiia. Kyiv: Kozari.

2. Education in Finland. (2018). Retrieved from https://www.unipage.net/ru/ study_in_finland.

3. Education in Greece. (2018). Retrieved from https://www.unipage.net/ru/ study_in_greece.

4. Education in Italy. (2018). Retrieved from https://www.unipage.net/ru/ study_in italy. in_norway.

5. Education in Norway. (2018). Retrieved from https://www.unipage.net/ru/study

6. Education in Spain. (2018). Retrieved from https://www.unipage.net/ru/ study_in spain.

7. Education in Sweden. (2018). Retrieved from https://www.unipage.net/ru/ study_in_sweden.

8. Hertsyk, A. (2006). Orhanizatsiino-metodychni aspekty pidhotovky bakalavriv fizychnoi reabilitatsii v Kanadi. (Avtoref. dys. kand. nauk z fiz. vykhovannia i sportu). National University of Physical Education and Sports of Ukraine, Kyiv.

9. Huk, S. (2015). Profesiina pidhotovka fakhivtsiv z fizychnoi Reabilitatsii $v$ universytetakh Velykoi Brytanii. (Avtoref. dys. kand. ped. nauk). Khmelnytskyi National University, Khmelnytskyi.

10. Karpiuk, R. (2008). Profesiina pidhotovka maibutnikh fakhivtsiv z adaptyvnoho fizychnoho vykhovannia: teoriia ta metodyka: monohrafiia. Lutsk: Volynska oblasna drukarnia.

11. Khmelnytskyi Natsionalnyi Universytet. (2018). Retrieved from http://www.khnu. $\mathrm{km} . u a /$ root/page.aspx.

12. Liannoi, Yu. (2016). Profesiina pidhotovka mahistriv z fizychnoi reabilitatsii $u$ vyshchykh navchalnykh zakladakh: teoretyko-metodychnyi aspekt. Sumy: Sumy State A. Makarenko Pedagogical University. 